\title{
자기공명영상장치의 정도관리에 관한 연구 The Study On Quality Control of Magnetic Resonance Imaging System
}

\author{
정천수 ${ }^{*}$, 임청환 ${ }^{* *}$ \\ 예닮치과병원", 한서대학교 방사선학과**
}

Cheon Soo Jeong(pitaki81@cyworld.com)*, Cheong-Hwan Lim(Ich116@hanseo.ac.kr) ${ }^{* *}$

\section{요약}

의료장비의 정도관리는 시스템 성능평가와 시스템의 유지 · 보수를 지속적으로 수행하고 다양한 측정 및 평가하여 의료정보의 정확성을 나타내기 위해 필요하여 한국의료영상품질관리원은 특수의료장비의 품질 관리 교육은 매년 정기적으로 실시하고 있다. 하지만 품질관리교육은 영상의학과 전문의 위주로 행해지고 있으며 의료기관에서도 영상의학과 전문의와 일부 방사선사에게 교육의 기회가 주어지지만 이차적인 내부 교육의 실시 또는 내용 전달 등이 미비하여 장비를 직접 다루는 방사선사들은 잘 모르거나 교육을 이수하였 더라도 정확히 모르고 있다. 본 연구는 2008년 대한자기공명기술학회에 등록된 전국의 방사선사를 대상으 로 설문을 실시하여 2008년 5월부터 9월까지 5 개월 동안 자료를 수집하여 분석하였다. 500 명을 대상으로 우편 설문조사를 실시하였으며, 설문응답률은 $6 \%(\mathrm{n}=180)$ 이었다. 본 연구 결과는 품질관리검사의 필요성은 $86.7 \%$ 가 필요하다고 느끼지만 특수의료장비 관리자 교육이수는 $27.8 \%$ 밖에 되지 않았고, 품질관리검사를 숙지하는 사람도 $53.9 \%$ 로 거의 절반 밖에 되지 않았다. 품질관리교육의 이수는 성별, 나이, 근무지의 규모, 근무지의 방사선사 인원, $\mathrm{MR}$ 실내의 방사선사 인원, 방사선사 경력 및 $\mathrm{MR}$ 실내의 경력과 병원에 의공학과 의 유무와 상관관계는 없었다. 한국의료영상품질관리원에서 실시하는 품질관리교육 이수자 중 $78.0 \%$ 가 검 사숙지를 하고 있는 것 $(\mathrm{p}<0.05)$ 에 비교하여 병원자체의 교육은 $43.9 \%$ 의 병원이 하고 있었지만 검사 숙지 자는 $54.4 \%$ 에 이르기 때문에 병원자체교육은 검사숙지에 큰 영향을 미치지 못하였다. 이는 교육의 내용, 교육의 방법, 교육이수에 대한 전반적인 환경요인이 품질관리교육에 얼마나 중요한지를 알 수가 있다.

중심어 : | 정도관리 | 자기공명영상 | 방사선사 | 교육 | 품질관리 |

\section{Abstract}

The quality control is needed to ensure the accuracy of medical information and achieved by evaluating the performance of and maintaining the system and practicing various measurements and evaluations. The Korean Institute for Accreditation of Medical Image, therefore, have held educational program for quality control of special medical equipments. The major of programs participants, however, are radiology specialists with only small number of radiological technologists from some hospitals, furthermore, the follow-up education and the share of information between participants and non-participants are insufficient in general, thus, the knowledge level of radiological technologists, regardless of their participation, is relatively low. This study carried out the questionnaire research for the 500 radiological technologists registered in Korean Society of MRI Technology, on the basis of 2008, and performed analysis for five months from May to Oct., 2008. The questionnaires were delivered by post to each radiological technologists and the response rate was $36 \%(n=180)$. The results of this revealed that the $86.7 \%$ of respondents felt the necessity of inspection on quality management, while only the $27.8 \%$ completed the educational program for manager of special medical equipment. and only the half(53.9\%) had the knowledge about inspection on quality management. The completion of educational program had no correlations with sex, age, size of occupying hospital, the number of radiological technologists in occupying site and MRI laboratory, career year of general radiologist and in MRI laboratory, and the presence of biomedical engineering department in occupying hospital. The $78.0 \%$ of participants at the educational program for quality management held by the Korean Institute for Accreditation of Medical Image had the knowledge about inspection on quality management $(\mathrm{p}<.05)$ whereas the $43.9 \%$ of the hospitals held such program and the $54.4 \%$ of radiological technologists from those hospitals had related knowledge, which indicated that such programs held by hospitals had not effects on the knowledge level of radiological technologists. This indicates also that the contents, methods, and other conditional factors of educational programs are important for the outcome of them.

keyword : | Quality Control | MRI | Radiological Technologist | Education I Quality Management |

* 이 논문은 2008년도 한서대학교 교비 학술연구 지원사업에 의하여 연구되었음.

접수번호 : \#090402-002

접수일자 : 2009년 04월 02일
심사완료일 : 2009년 05월 27일

교신저자 : 임청환, e-mail : Ich116@hanseo.ac.kr 


\section{I. 서 론}

현대 의료의 방사선을 이용한 진단적 검사에는 $\mathrm{X}$ 선 발생장치, 투시조영장치, 전산화단층촬영장치, 초음파 장치, 자기공명영상장치, 핵의학 영상장치 등의 다양하 고 발달된 의료영상기기가 이용되고 있다.

그러나 의료영상기기는 지속적으로 성능이 일정하게 유지되는 것은 아니므로 장비의 수명 저하에 따른 관리 와 보수·유지가 절대적으로 요구되며 필요하는데 이 를 품질보증(Quality Assurance, $\mathrm{QA})$, 정도관리 (Quality Control, QC)로 명명하고 있다.

의료영상에서의 정도관리 $(\mathrm{QC})$ 란 의료영상기기가 제 공하는 의료정보의 정확성을 보장하기 위한 최소한의 시스템 성능 평가와 시스템 유지 보수를 지속적으로 수 행되는 다양한 측정 및 평가 등 일련의 작업이라 할 수 있다. 대부분의 의료영상기기들은 시간경과 및 사용 정 도에 따라 성능이 떨어지거나 변하기 때문에 정확한 성 능 평가와 이에 따른 지속적인 보정작업은 반드시 필요 하다고 할 수 있다[1].

그러나 의료영상기기에서 시간의 경과에 따라 영상 의 품질이 서서히 저하되는 경우는 그 문제점 노출이 어려우며, 영상장치의 복잡성과 정밀성으로 문제가 생 기더라도 정확한 문제부위를 파악하여 적정한 대응조 치를 취하기 어려운 경우가 많다. 이는 결과적으로 효 율적인 환자관리에 지장을 초래하게 된다[2].

현재 의료영상기기에 대한 정도관리는 2002년 국민 건강보험재정건전화특별법을 시작으로 2008년에 이르 기까지 특수의료장비의 설치 및 운영에 관한 규칙이 개 정하면서 실시되고 있다[3]. 이는 의료영상장비의 효율 적인 활용으로 인하여 불필요한 의료행위를 감소하고, 의료영상의 질을 향상시켜 방사선피폭을 최소화하므로 국민 의료비 과잉 지출을 억제하고 안전하고 질 높은 진료를 함으로써 국민건강권을 확보하고자 시행되고 있다.

제정된 법령에 따른 특수의료장비의 정도관리 실태 와 의료장비의 평가를 실시하는 기관으로 한국의료영 상품질관리원은 시스템 성능 평가와 시스템의 유지 · 보수를 지속적으로 수행하고 다양한 측정 및 평가하여 의료정보의 정확성을 나타내기 위해 필요한 특수의료
장비의 품질관리 교육을 매년 정기적으로 실시하고 있 다. 하지만 품질관리교육은 영상의학과 전문의 위주로 행해지고 있으며 의료기관에서도 영상의학과 전문의와 일부 방사선사에게 교육의 기회가 주어지지만 이차적 인 내부교육의 실시 또는 내용 전달 등이 미비하여 장 비를 직접 다루는 방사선사들은 잘 모르거나 교육을 이 수하였더라도 정확히 모르고 있다. 그리고 품질관리교 육을 이수했다 하더라도 장비의 오류 시 교육을 이수한 자가 오류해결을 하는 게 아니라 계약한 장비회사와 연 결해서 해결을 하고 있다. 또한 병원의 의공학과에서 정기점검을 시행해야 함에도 불구하고 시행되지 않고 있으며 오류 발생 시 해결도 못하고 있는 실정이다.

이에 본 연구에서는 자기공명영상장치(Magnetic Resonance Imaging : 이하 MRI)에 대하여 한국의료영 상품질관리원의 품질관리검사의 실태와 그 유용성에 관한 설문을 통하여 첫째, 자기공명영상장치 정기점검 에 대한 분석, 둘째, 품질관리에 대한 분석, 셋째, 일반 적 특성에 따른 교육 이수에 대한 상관성 분석, 넷째, 교 육 이수 여부에 따른 검사 숙지의 상관성 분석, 다섯째, 자체교육 여부에 따른 검사 숙지의 상관성 분석을 실시 하여 자기공명영상장치의 정도관리에 대한 인식과 품 질관리검사의 실태에 대하여 알아보고자 한다.

\section{II. 연구대상 및 방법}

\section{1. 연구 대상}

본 연구를 위한 조사 대상은 2008년도 대한자기공명 기술학회에 등록된 전국의 방사선사를 대상으로 선정 하여 MR장비 정도관리 현황, 한국의료영상품질관리원 의 품질관리검사의 타당성 등의 실태를 분석하기 위해 현재 의료기관에서 MRI 검사 담당 방사선사에게 자기 기입식 설문지 조사(Self administered questionnaire survey)를 통하여 실시하였다. 지역으로는 서울·경기 도 지역 19 개, 충청도 4 개, 경상도 6 개, 전라도 8 개, 강원 도 3 개, 제주도 2 개의 병원으로 총 42 개 병원이었다. 500 명을 대상으로 설문조사를 실시한 결과 180명이 응 답하여 $36 \%$ 의 응답률이었다[표 2]. 


\section{2. 조사 방법}

본 연구의 자료 수집을 위한 조사 방법은 $\mathrm{MR}$ 장비의 정도관리에 대한 설문지를 작성하여 2008년 5월 광주, 전남의 23 명의 방사선사를 대상으로 예비조사를 하였 다. 예비조사로 설문조사 전에 응답자에게 설문의 목적 및 개요와 작성요령 등을 설명한 후 조사하였으며, 예 비조사 결과를 통하여 $\mathrm{MRI}$ 장비의 정도관리의 실태를 파악 후 설문지의 사항을 수정, 보완하여 일반적 특성, $\mathrm{MR}$ 장비의 관리에서 $\mathrm{MRI}$ 장비의 형태와 정기점검사항, 한국영상품질관리원의 검사의 타당성과 미비점 등을 설문하였다. 연구자가 직접 또는 우편으로 배부하고 회 수하였다. 본 조사의 경우 2008년 5월부터 9월까지 5개 월 동안 실시하였다.

\section{3. 자료 처리 및 분석}

수집된 자료는 지역별로 분류하고 통계 패키지 프로 그램 SPSS(Statistical Package for the Social Science) version 12.0 을 이용하여 시행하였다. 신뢰구간 $95 \%$ 이 상인 경우를 $(\mathrm{p}<0.05)$ 통계적으로 유의성이 있는 것으로 판정하였다.

\section{III. 연구 결과}

\section{1. 자기공명영상장치 정기점검에 대한 분석}

\section{1 정기점검의 필요성 인식}

정기점검에 대한 필요성 인식을 살펴보면 156명 (86.7\%)이 매우 필요하다고 인식했고, 23명(12.8\%)가 필요하다고 응답한 것으로 보아 거의 대부분 정기점검 이 꼭 필요하다고 인식하고 있었다[표 1].

\section{표 1. 정기점검의 필요성 인식}

\begin{tabular}{lcc}
\hline \multicolumn{1}{c}{ 정기 점검의 필요성 인식 } & 빈도 & 백분율 \\
\hline \hline 매우 필요하다 & 156 & 86.7 \\
\hline 필요하다 & 23 & 12.8 \\
\hline 보통이다 & 1 & 0.6 \\
\hline 필요하지 않다 & 0 & 0 \\
\hline 전혀 필요하지 않다 & 0 & $\cdot 0$ \\
\hline
\end{tabular}

\section{2 정기점검의 실천도 분석}

병원별 장비의 정기점검에 대한 실천도를 살펴보면 163 명(90.6\%)는 항상 점검하고 있다고 하였으며, 17 명 (9.4\%)는 보통 점검한다는 것으로 보아 대부분의 병원 에서 $\mathrm{MR}$ 장비의 정기점검은 잘 되고 있었다[표 2].

표 2. 정기점검의 실천도 분석

(단위 : 명, \%)

\begin{tabular}{lcc}
\hline \multicolumn{1}{c}{ 실천도 분석 } & 빈도 & 백분율 \\
\hline \hline 항상 점검한다 & 163 & 90.6 \\
\hline 점검한다 & 17 & 9.4 \\
\hline 저ㅁㅓㅓㅁ하지 않는다 & 0 & 0 \\
\hline 전혀 점검하지 않는다 & $\cdot 0$ & 0 \\
\hline
\end{tabular}

\section{3 정기점검의 시행방법}

정기점검에 대한 시행방법을 살펴보면 의료장비회사 와 계약하여 검사하는 곳이 $98.3 \%$ 이며, 의공학과에서 정기점검을 검사하는 곳은 $1.7 \%$ 로 나타났다.

대부분의 병원이 의공학과를 설치운영하고 있으면서 도 MRI장비의 정기점검은 의료장비회사에 위탁하는 것을 알 수 있다[표 3].

표 3. 정기점검의 시행방법 (단위 : 명, \%)

\begin{tabular}{lcc}
\hline \multicolumn{1}{c}{ 정기 점검의 시행방법 } & 빈도 & 백분율 \\
\hline \hline 계약한 장비회사에서 검사 & 177 & 98.3 \\
\hline 병원 의공학과에서 검사 & 3 & 1.7 \\
\hline
\end{tabular}

\section{4 정기점검 후 결과 인식과 공유}

$\mathrm{MRI}$ 장치의 정기점검 후의 사용 장비에 대한 결과 인 식과 구성원 간에 점검 결과의 공유여부를 빈도분석을 통하여 살펴보았다.

정기점검 후의 결과 인식은 180 명 중 166 명(92.2\%)이 결과를 알고 있었으며[표 4], 정기점검 후의 결과 에 대 한 공유는 169명 중 161명(95.3\%)이 공유를 하고 있는 것으로 보아 대부분의 병원에서 장비의 정기점검에 대 한 결과 인식과 정보의 공유가 잘 되고 있었다[표 5]. 
표 4. 정기점검 결과의 인식

(단위 : 명, \%)

\begin{tabular}{lll}
\hline \multicolumn{1}{c}{ 정기 점검 결과 } & 빈도 & 백분율 \\
\hline \hline 알고 있다 & 166 & 92.2 \\
\hline 모른다 & 11 & 6.1 \\
\hline 기타 & 3 & 1.7 \\
\hline
\end{tabular}

표 5. 정기 점검 결과의 공유

(단위 : 명, \%)

\begin{tabular}{lll}
\hline \multicolumn{1}{c}{ 정기 점검 결과 } & 빈도 & 백분율 \\
\hline \hline 공유한다 & 161 & 95.3 \\
\hline 공유하지 않는다 & 6 & 3.5 \\
\hline 기타 & 2 & 1.2 \\
\hline
\end{tabular}

\section{2. 품질관리에 대한 분석}

\section{1 품질관리검사 교육 이수 분석}

한국의료영상품질관리원에서 실시하는 $\mathrm{MR}$ 장비의 품질관리검사 교육의 이수여부를 분석한 결과, 이수하 지 않은 사람이 130 명 $(72.2 \%)$ 으로 이수한 사람 50명 (27.8\%)보다 $44.4 \%$ 가 더 많았다. 이는 대부분이 장비관 리 책임자로 지정된 영상의학과 전문의들의 위주로 품 질관리검사 교육이 시행되고 있었기 때문이다[표 6].

표 6. 품질관리검사 교육 이수 여부 (단위 : 명, \%)

\begin{tabular}{lll}
\hline \multicolumn{1}{c}{ 품질관리검사 교육 이수 여부 } & 빈도 & 백분율 \\
\hline \hline 이수하였다 & 50 & 27.8 \\
\hline 이수하지 않았다 & 130 & 72.2 \\
\hline
\end{tabular}

\section{2 병원 자체 교육 실시 여부}

병원의 $\mathrm{MRI}$ 실 내부에서 품질관리검사에 대하여 자 체적으로 교육의 실시 여부를 분석한 결과, $43.9 \%$ 가 실 시하고 있었으며, $56.1 \%$ 는 실시하지 않는 것으로 나타 나 거의 절반이상이 내부 교육을 실시하고 있지 않았다 [표 7].

표 7. 병원 자체 교육 실시 여부

(단위 : 명, \%)

\begin{tabular}{llc}
\hline \multicolumn{1}{c}{ 병원자체 교육 실시 여부 } & 빈도 & 백분율 \\
\hline \hline 실시한다 & 79 & 43.9 \\
\hline 실시하지 않는다 & 101 & 56.1 \\
\hline
\end{tabular}

\section{3 품질관리검사의 숙지 여부}

한국의료영상품질관리원의 품질관리검사에 대하여 숙지하는지의 여부를 분석한 결과, 알고 있는 사람이 97명(53.9\%), 모르고 있는 사람이 83명(46.1\%)으로 알 고 있는 사람이 $7.8 \%$ 더 많긴 하지만 절반 수준밖에 안 되기 때문에 더 많은 검사숙지를 위해서는 체계적인 교 육이 필요할 것이다[표 8].

표 8. 품질관리검사 숙지 여부

(단위 : 명, \%)

\begin{tabular}{lcc}
\hline \multicolumn{1}{c}{ 품질관리검사 숙지 여부 } & 빈도 & 백분율 \\
\hline \hline 알고 있다 & 97 & 53.9 \\
\hline 모른다 & 83 & 46.1 \\
\hline
\end{tabular}

3. 일반적 특성에 따른 교육 이수에 대한 상관성 분석

일반적 특성에 따른 교육 이수의 전체 결과를 보면, 총 180 명 중 이수자는 50명(27.8\%), 미이수자는 130 명 (72.2\%)으로 나타났다. 교차분석을 통해 빈도와 백분 율, 유의성을 알아보았으며, 그 결과는 다음과 같다.

\section{1 성별}

성별에 따른 교육 이수 여부를 살펴보면, 남자 중 교 육 이수자는 44명(29.5\%), 미이수자는 105명(70.5\%)이 며, 여자 중 교육 이수자는 6명(19.4\%), 미이수자는 25 명 $(80.6 \%)$ 의 빈도를 보였다. 성별에 따른 교육 이수는 남, 녀 모두 저조한 것을 알 수 있었고, 성별과 교육이수 와는 상관관계는 성립하지 않았다[표 9].

표 9. 성별에 따른 교육 이수여부

(단위 : 명, \%)

\begin{tabular}{cccc}
\hline 성 별 & 이수자 & 미이수자 & 계 \\
\hline \hline \multirow{2}{*}{ 남 자 } & 44 & 105 & 149 \\
& 29.5 & 70.5 & $100 \%$ \\
\hline \multirow{2}{*}{ 여 자 } & 6 & 25 & 31 \\
& 19.4 & 80.6 & $100 \%$ \\
\hline
\end{tabular}

\section{2 연령}

연령에 따른 교육 이수여부를 살펴보면, 50세 이상의 이수자가 $40.0 \%$ 로 가장 많았으며 20 29세의 이수자가 
$12.5 \%$ 로 가장 낮은 빈도를 보였다. 연령이 높아짐에 따 라 교육 이수가 많아지는 것으로 보아 장비의 책임자들 이 교육 이수를 많이 하는 것을 알 수 있었고 연령에 따 른 교육 이수는 상관관계가 성립하지 않았다[표 10].

표 10. 연령에 따른 교육 이수여부

(단위 : 명, \%)

\begin{tabular}{cccc}
\hline 연 령 & 이수자 & 미이수자 & 계 \\
\hline \multirow{2}{*}{ 20 29세 } & 4 & 28 & 32 \\
& 12.5 & 87.5 & $100 \%$ \\
\hline \multirow{2}{*}{ 30 39세 } & 22 & 55 & 77 \\
& 28.6 & 71.4 & $100 \%$ \\
\hline \multirow{2}{*}{ 40 49세 } & 20 & 41 & 61 \\
& 32.8 & 67.2 & $100 \%$ \\
\hline \multirow{2}{*}{ 50세 이상 } & 4 & 6 & 10 \\
& 40.0 & 60.0 & $100 \%$ \\
\hline
\end{tabular}

\section{3 근무지 규모}

근무지 규모에 따른 교육 이수여부를 살펴보면, 500 병상 이하가 $31.3 \%$ 로 가장 많이 빈도를 보였다. 비교 적 작은 규모의 병원에 근무자들이 큰 규모의 병원에 근무자보다 많이 이수한 것을 알 수 있었다. 근무지 규 모와 교육 이수와 상관관계가 성립하지 않았다[표 11].

표 11. 근무지 규모에 따른 교육 이수여부 (단위 : 명, \%)

\begin{tabular}{cccc}
\hline 규 모 & 이수자 & 미이수자 & 계 \\
\hline \hline \multirow{2}{*}{ 500병상 이하 } & 10 & 22 & 32 \\
& 31.3 & 68.8 & $100 \%$ \\
\hline \multirow{2}{*}{ 501병상 1000병상 } & 25 & 42 & 67 \\
& 37.3 & 62.7 & $100 \%$ \\
\hline \multirow{2}{*}{ 1001병상 1500병상 } & 2 & 11 & 13 \\
& 15.4 & 84.6 & $100 \%$ \\
\hline \multirow{2}{*}{ 1501병상 2000병상 } & 8 & 40 & 48 \\
& 16.7 & 83.3 & $100 \%$ \\
\hline \multirow{2}{*}{ 2001병상 이상 } & 5 & 15 & 20 \\
& 25.0 & 75.0 & $100 \%$ \\
\hline
\end{tabular}

\section{4 근무지의 방사선사 인원}

근무지의 방사선사 인원에 따른 교육 이수여부를 살 펴보면, 근무처의 방사선사가 40 명 이하인 곳이 $41.4 \%$ 로 가장 교육 이수를 많이 하였으며, 근무지의 방사선
사 인원이 121 명 이상인 곳은 $80.9 \%$ 로 가장 많이 이수 하지 않았다. 근무지의 방사선사 인원과 교육 이수와의 관계는 상관관계가 성립하지 않았다[표 12].

표 12. 방사선사 인원에 따른 교육 이수여부 (단위 : 명, \%)

\begin{tabular}{rccc}
\hline 방사선사 인원 & 이수자 & 미이수자 & 계 \\
\hline \hline \multirow{2}{*}{40 명 이하 } & 24 & 34 & 58 \\
& 41.4 & 58.6 & $100 \%$ \\
\hline \multirow{2}{*}{41 명 80명 } & 11 & 36 & 47 \\
& 23.4 & 76.6 & $100 \%$ \\
\hline \multirow{2}{*}{81 명 120명 } & 2 & 5 & 7 \\
& 28.6 & 71.4 & $100 \%$ \\
\hline \multirow{2}{*}{ 121명 이상 } & 13 & 55 & 68 \\
& 19.1 & 80.9 & $100 \%$ \\
\hline
\end{tabular}

\subsection{MRI실내의 방사선사 인원}

$\mathrm{MRI}$ 실내의 방사선사 인원에 따른 교육이수 여부를 살펴보면, 5 명 이하가 $34.6 \%$ 로 교육을 가장 많이 이수 하였고, 21 명 이상이 $16.7 \%$ 로 교육이수가 가장 낮았다. $\mathrm{MRI}$ 실내의 방사선사 인원은 교육이수와 상관관계가 성립하지 않았다[표 13].

표 13. MRI실내 방사선사 인원에 따른 교육 이수여부

(단위 : 명, \%)

\begin{tabular}{cccc}
\hline MRI실 방사선사 & 이수자 & 미이수자 & 계 \\
\hline \hline \multirow{2}{*}{ 5명 이하 } & 27 & 51 & 78 \\
& 34.6 & 65.4 & $100 \%$ \\
\hline \multirow{2}{*}{ 6명 10명 } & 8 & 19 & 27 \\
& 29.6 & 70.4 & $100 \%$ \\
\hline \multirow{2}{*}{ 11명 15명 } & 2 & 5 & 7 \\
& 28.6 & 71.4 & $100 \%$ \\
\hline \multirow{2}{*}{ 16명 20명 } & 5 & 15 & 20 \\
& 25.0 & 75.0 & $100 \%$ \\
\hline \multirow{2}{*}{ 21명 이상 } & 8 & 40 & 48 \\
& 16.7 & 83.3 & $100 \%$ \\
\hline
\end{tabular}

\section{6 방사선사 경력}

방사선사의 경력에 따른 교육이수 여부는 16 20년 이 $37.5 \%$ 로 가장 많았으며, 21 년 이상도 $33.3 \%$ 로 높은 빈도를 보였다. 경력이 많을수록 교육 이수의 빈도가 높은 것으로 보아 장비 책임자들이 교육이수를 많이 한 
것을 알 수 있었고, 방사선사 경력은 교육 이수와 상관 관계가 성립하지 않았다[표 14].

표 14. 방사선사 경력에 따른 교육 이수여부 (단위 : 명, \%)

\begin{tabular}{cccc}
\hline 방사선사 경력 & 이수자 & 미이수자 & 계 \\
\hline \hline \multirow{2}{*}{ 5년 이하 } & 9 & 34 & 43 \\
& 20.9 & 79.1 & $100 \%$ \\
\hline \multirow{2}{*}{ 6년 10년 } & 13 & 28 & 41 \\
& 31.7 & 68.3 & $100 \%$ \\
\hline \multirow{2}{*}{ 11년 15년 } & 10 & 36 & 46 \\
& 21.7 & 78.3 & $100 \%$ \\
\hline \multirow{2}{*}{ 16년 20년 } & 12 & 20 & 32 \\
& 37.5 & 62.5 & $100 \%$ \\
\hline \multirow{2}{*}{ 21년 이상 } & 6 & 12 & 18 \\
& 33.3 & 66.7 & $100 \%$ \\
\hline
\end{tabular}

\subsection{MR실내의 경력}

$\mathrm{MRI}$ 실내의 경력에 따른 교육이수 여부를 살펴보면, 7 9년이 42.9\%로 가장 많았으며, 7년 이상의 경력자들 이 교육 이수의 빈도가 높은 것으로 보아 실질적인 장 비 책임자들이 교육이수를 많이 한 것을 알 수 있었고, $\mathrm{MR}$ 실내의 경력은 교육 이수와 상관관계가 성립하지 않았다[표 15].

표 15. MRI실내 경력에 따른 교육 이수여부 (단위 : 명, \%)

\begin{tabular}{cccc}
\hline MRI실내의 경력 & 이수자 & 미이수자 & 계 \\
\hline \hline \multirow{2}{*}{ 3년 이하 } & 17 & 71 & 88 \\
& 19.3 & 80.7 & $100 \%$ \\
\hline \multirow{2}{*}{ 4년 6년 } & 13 & 29 & 42 \\
& 31.0 & 69.0 & $100 \%$ \\
\hline \multirow{2}{*}{ 7년 9년 } & 6 & 8 & 14 \\
& 42.9 & 57.1 & $100 \%$ \\
\hline \multirow{2}{*}{ 10년 12년 } & 7 & 12 & 19 \\
& 36.8 & 63.2 & $100 \%$ \\
\hline \multirow{2}{*}{ 13년 이상 } & 7 & 10 & 17 \\
& 41.2 & 58.8 & $100 \%$ \\
\hline
\end{tabular}

\section{8 의공학과 유무}

의공학과의 유무에 따른 교육이수 여부를 살펴보면, 의공학과가 있는 곳의 이수자는 $28.7 \%$, 의공학과가 없 는 곳의 이수자는 $21.7 \%$ 로, 의공학과의 유무는 교육 이
수에 크게 영향을 미치지 않았으며, 상관관계 또한 성 립하지 않았다[표 16].

표 16. 의공학과 유무에 따른 교육 이수여부 (단위 : 명, \%)

\begin{tabular}{cccc}
\hline 의공학과 유무 & 이수자 & 미이수자 & 계 \\
\hline \hline \multirow{2}{*}{ 있다 } & 45 & 112 & 157 \\
& 28.7 & 71.3 & $100 \%$ \\
\hline \multirow{2}{*}{ 없다 } & 5 & 18 & 23 \\
& 21.7 & 78.3 & $100 \%$ \\
\hline
\end{tabular}

\section{4. 교육 이수 여부에 따른 검사 숙지의 상관성 분석}

한국의료영상품질관리원의 특수의료장비 관리자 교 육이수 여부에 따른 품질 관리검사의 숙지의 상관성을 교차 분석을 통해 빈도와 백분율, 유의성을 알아보았다. 이수자 중 품질관리검사를 알고 있는 사람은 39명 (78.0\%), 모르고 있는 사람은 11 명(22.0\%)를 보였으며, 미이수자 중 품질관리검사를 알고 있는 사람은 58명 (44.6\%), 모르고 있는 사람은 72명(55.4\%)의 빈도를 보 였다. 특수의료장비 관리자 교육 이수 여부에 따른 품 질관리 검사의 숙지와의 상관관계에서는 유의성이 있 는 것으로 나타났다(p〈0.05)[표 17].

표 17. 교육 이수 여부에 따른 결과 숙지 (단위 : 명, \%)

\begin{tabular}{cccc}
\hline 이수 여부 & 알고 있다 & 모른다 & $p$-value \\
\hline \hline \multirow{2}{*}{ 이수자 } & 39 & 58 & \\
& 78.0 & 44.6 & $\mathrm{p}=0.000$ \\
\hline \multirow{2}{*}{ 미이수자 } & 11 & 72 & \\
& 22.0 & 55.4 & $\mathrm{p}=0.000$ \\
\hline \hline \multirow{2}{*}{ 계 } & 50 & 130 & \\
& $100 \%$ & $100 \%$ & \\
\hline
\end{tabular}

\section{5. 자체교육 여부에 따른 검사 숙지의 상관성 분석}

병원자체에서 품질관리교육 여부에 따른 품질관리검 사의 숙지에 대한 상관성을 교차분석으로 빈도, 백분율, 유의성을 알아보았다. 품질관리교육을 실시한 병원에 서 검사 숙지자는 43 명 $(54.4 \%)$, 미숙지자는 36명 (45.6\%)이며, 품질관리 교육을 미실시한 병원에서 검사 숙지자는 54명(53.5\%), 미숙지자는 47명(46.5\%)의 빈도 를 보였으며, 통계적으로 상관관계가 성립하지 않았다 
(p) 0.05)[표 18].

표 18. 자체교육에 따른 결과 숙지

\begin{tabular}{cccc}
\hline 자체교육 & 알고 있다 & 모른다 & 계 \\
\hline \multirow{2}{*}{ 실시 } & 43 & 36 & 79 \\
& 54.4 & 45.6 & $100 \%$ \\
\hline \multirow{2}{*}{ 미실시 } & 54 & 47 & 101 \\
& 53.5 & 46.5 & $100 \%$ \\
\hline
\end{tabular}

\section{IV. 고 찰}

본 연구는 MRI장비 정도관리의 실태와 유용성을 알 아보기 위해 정도관리에 대한 항목, 문항 설계[4]를 하 고, 응답 항목 형태변형[5]을 하여 설문지를 작성하였 다. 설문은 2008년 대한자기공명기술학회에 등록된 전 국의 방사선사를 대상으로 2008년 5월부터 9월까지 5 개월 동안 자료를 수집하여 분석하였다. 500명을 대상 으로 우편 설문조사를 실시하였으며, 설문응답률은 수 도권 19 개, 충청권 4 개, 영남권 6 개, 호남권 8 개, 강원권 3 개, 제주도 2 개의 병원이고, 전국 42 개병원 180 명으로 $36 \%$ 이었다. 설문 응답의 절반이 수도권에 집중되었지 만 나머지는 비교적 고른 결과를 얻을 수 있었다.

정도관리란 신뢰성 있는 검사 결과를 얻기 위하여 분 석 및 분석 전후의 과정에 관여하는 오류를 최소화 하 고자 하는 일련의 과학적인 노력이며 기준된 자료의 신 뢰도를 확보하기 위하여 자료의 정확도(Accuracy)와 정밀도(Precision)를 원하는 수준까지 도달케 하는데 그 목적이 있다[6]. 본 연구에서는 정도관리의 시작단계 라 할 수 있는 $\mathrm{MRI}$ 장비의 정기점검에 대한 분석을 한 결과, $86.7 \%$ 가 매우 필요하다고 인식하고, $90.6 \%$ 가 항 상 점검하고 있었다[표 1]. 정기점검에 대한 필요성과 실천도는 비교적 높은 것을 알 수 있었다. 또한 정기점 검의 결과를 숙지하는 사람은 $92.2 \%$, 결과의 공유도 95.3\%로 높은 결과를 보였다[표 4][표 5]. 하지만 정기 점검의 시행은 $98.3 \%$ 의 병원이 의료장비회사에 위탁하 여 정기점검과 품질관리검사를 실시하고 있었다. $87.2 \%$ 의 병원이 의공학과를 설치운영하고 있으면서도 $\mathrm{MR}$ 장비의 정기점검은 의료장비회사에 위탁하는 것은
병원이 이중적으로 많은 비용을 감수하면서 MRI장비 를 운영하고 있는 것을 알 수가 있다[표 3].

품질관리검사에 대한 분석을 한 결과, 한국의료영상 품질관리원에서 실시하는 특수의료장비 관리자 교육을 이수한 사람은 $27.8 \%$ 로 이는 장비관리 책임자로 지정 된 영상의학과 전문의들의 위주로 품질관리검사 교육 이 시행되고 있음을 알 수 있다[표 6]. 그리고 자체적으 로 교육의 실시 여부를 분석한 결과, $43.9 \%$ 가 실시하고 있었으며, $56.1 \%$ 는 실시하지 않는 것으로 나타나 거의 절반이상이 내부 교육을 실시하고 있지 않았다[표 7]. 장비관리 책임자로 지정된 영상의학과 전문의들의 위 주의 교육과 실질적인 장비관리와 운영자인 방사선사 와의 품질관리검사 교육내용의 전달이 이루어지지 않 음도 알 수 있다.

한편, 일반적 특성에 따른 교육 이수에 대한 상관성 을 분석한 결과, 성별, 나이, 근무지의 규모, 근무지의 방사선사 인원, $\mathrm{MRI}$ 실내의 방사선사 인원, 방사선사 경 력 및 $\mathrm{MRI}$ 실내의 경력과 병원내 의공학과의 유무는 품 질관리교육의 이수와 관계가 없는 것으로 나왔다.

교육 이수 여부에 따른 검사 숙지의 상관성을 분석한 결과, 이수자 중 품질관리검사를 알고 있는 사람은 $78.0 \%$, 모르고 있는 사람은 $22.0 \%$ 였으며, 미이수자 중 품질관리검사를 알고 있는 사람은 $44.6 \%$, 모르고 있는 사람은 $55.4 \%$ 로 나타났다 $(\mathrm{p}<0.05)$ [표 17]. 품질관리교 육을 이수한 사람이 이수하지 않은 사람보다 많이 품질 관리검사 내용을 숙지하는 것으로 보아 지속적인 교육 이 이루어져야 하겠다.

품질관리검사에 대한 내용을 숙지하고 있는 사람이 $53.9 \%$ 로 교육의 필요성을 요구되었던바[7], 본 연구는 병원 자체에서 실시하는 교육에 따른 검사 숙지의 상관 성을 분석한 결과, 품질관리교육을 실시한 병원에서 검 사 숙지자는 $54.4 \%$, 미숙지자는 $45.6 \%$ 이며, 품질관리 교육을 미실시한 병원에서 검사 숙지자는 $53.5 \%$, 미숙 지자는 $46.5 \%$ 의 결과를 보여 병원 자체의 교육은 실제 검사 숙지에는 크게 영향을 미치지 못하는 것으로 나타 났다[표 18]. 특수의료장비관리자 교육 이수자 중 78\% 가 검사 숙지를 하고 있는 반면 병원 자체의 교육자 중 $54.4 \%$ 가 검사 숙지를 하여 $23.6 \%$ 의 차이를 보였다. 이 
는 병원 자체 교육에서 교육자의 교육 준비 미흡이나 피교육자의 교육에 대한 성실성, 중요도 인식의 결여와 병원에서 교육시간에 대한 배려 등이 결여되었다고 보 여 진다. 반면, 한국의료영상품질관리원의 특수의료장 비관리자 교육은 전적으로 1 일에 병원 이외의 장소와 근무시간에 규제없이 이루어지기 때문에 검사숙지가 더 높은 것으로 보인다[8].

본 연구에서는 몇 가지 제한점을 가지고 있다.

첫째, 대한자기공명기술학회에 등록된 방사선사가 근무한 병원에 한하여 설문을 실시했지만, 300병상 이 하의 작은 병원의 설문을 수집하지 못한 점이다.

둘째, 수집된 설문지를 분석한 결과 42 개의 병원 중 19 개의 병원이 수도권에 치중되어 있었다. 지방의 대학 병원급에서만 설문에 응해 전국적인 결과가 고루 반영 되지 못하였다.

셋째, 품질관리검사가 대부분 계약한 장비업체에서 알아서 시행하고 있었다. 장비를 직접 다루는 방사선사 가 알아야 하는 부분이 있기 때문에 교육의 정도와 숙 지 정도의 객관성이 파악되지 않은 주관적 부분에 치중 되었다.

넷째, 특수의료장비의 관리자가 영상의학과 전문의 로 되어 있으면서도 대부분의 병원에서 장비의 설치, 운영, 오류 확인 등에 실질적인 관리자는 방사선사로 되어 있음도 여러 가지 시사하는 바가 크다.

\section{V. 결 론}

임상의 필수적인 영상장치로 선호되고 있는 $\mathrm{MR}$ 장비 의 품질검사는 매우 중요하다. 한국의료영상품질관리 원은 특수의료장비 관리자 교육의 기회를 1 년에 여러 회에 지역적으로 조정을 하고 홍보도 왕성하게 하여 많 은 사람들이 품질관리검사 숙지를 할 수 있도록 해야 할 것으로 사료된다. 각 병원들도 자체 교육을 실시하 고 있지만 많은 사람들이 품질관리검사숙지가 안 되는 것으로 보아 교육 내용을 잘 만들어 주기적으로 해야 할 것이다. 또한 영상의학과 전문의나 계약한 장비업체 가 품질관리검사를 하는 것보다 장비를 직접 다루는 방
사선사가 직접 품질관리검사를 실시하는 것이 시간적, 비용적 측면에서 적합하다 하겠다.

$\mathrm{MRI}$ 장비의 관리자가 영상의학과 전문의로 되어 있 는 부분과 품질관리교육을 장비를 직접 관리하고 운용 하는 방사선사가 배제되는 부분 및 교육내용의 전달 체 계는 개선되어야할 사항으로 사료되며, 향후 품질관리 항목들을 구체적으로 연구하여 정확한 품질관리의 가 이드라인을 만들고 임상에서 더욱 활용해야 되겠다.

\section{참 고 문 헌}

[1] 김영일, 진료영상기기 $Q C$, 대학서림, pp.281-289, 1993.

[2] 서울아산병원, $M R Q C \&$ Recent Advances in Neuro study, pp.8-9, 2007.

[3] 고관용, 의료관계법규(의료법 제 38 조, 특수의료장 비의 설치·운영), 현문사, pp.78-79, 2008.

[4] 문숙경, 설문지 항목 / 문항 설계에 관한 연구, 사회과학연구, pp.197-202, 1999.

[5] 유종영, 설문지 응답 항목 형태변형에 다른 통계 적 고찰, 산업경영논총, pp.79-94, 1999.

[6] 김준규, $1.5 T$ 초전도 자기공명영상시스템에서 발 생되는 오류의 원인 분석과 정도관리에 관한 연 구, 건국대학교 석사논문, pp.5-8, 2001.

[7] 함형규, 자기공명영상 화질평가 항목개발에 대한 연구, 을지대학교 석사논문, 2008.

[8] 한국의료영상품질관리원, 2008년도 특수의료장비 관리자 교육, pp.3-95, 2008.

[9] U. Fischer, A multipurpose phantom for quality assurance of contrast-enhanced MR imaging of the breast European radiology, pp.162-166, 2000.

[10] C. C. Chen, Quality Assurance of Clinical MRI Scanners Using ACR MRI Phantom: Preliminary Results. Journal of digital imaging, pp.279-284, 2004.

[11] 김장섭, Multipurpose Phantom을 이용한 자기 공명 영상장치의 정도분석, 고려대학교 석사논문, 
pp.18-20, 2003.

[12] 양한준, 국내 CT장치의 성능평가에 관한 연구, 대한방사선기술학회, 제25권, 제2호, pp.83-95, 2002.

[13] 이종호, 국제품질보증규격(ISO 9000 시리즈)에 근거한 품질경영체제 구축방안, 제 17 권, 제 2 호, pp.52-53, 1995.

[14] R. R. Price, Quality assurance methods and phantoms for magnetic resonance imaging: report of AAPM nuclear magnetic resonance Task Group No. 1. Medical physics. pp.287-295, 1990.

[15] R. A. Lerski, Performance assessment and quality control in MRI by Eurospin test objects and protocols. Magnetic resonance imaging, pp.817-833, 1993.

\section{저 자 소 개}

정 천 수 (Cheon Soo Jeong)

정회원

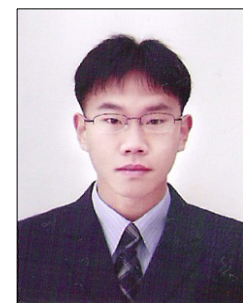

- 2009년 2월 : 한서대학교 대학원 방사선학과(방사선학 석사)

- 2008년 6월 현재 : 예닮치과 병원

- 2008년 3월 현재 : 목포과학 대학 시간강사

<관심분야> : 방사선학, 영상정보학 자기공명영상학

임 청 환 (Cheong-Hwan Lim)

정회원

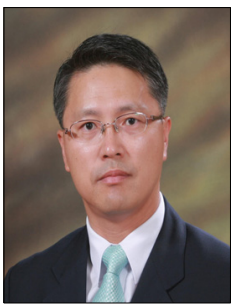

- 1997년 8월 : 단국대학교 대학원 보건행정학과(보건학 석사)

- 2005년 2월 : 경원대학교

의료경영학과(보건학 박사)

- 2001년 3월 현재 : 한서대학 교 방사선학과 교수

<관심분야> : 방사선학, 보건정보학, 자기공명영상학 